\title{
Synthesis, crystal structure, thermal analysis, and electrical properties of bis tetrapropylammonium hexachloro-dizincate compound
}

\author{
M. Ben Gzaiel • A. Oueslati • I. Chaabane • A. Bulou • \\ F. Hlel • M. Gargouri
}

Received: 10 May 2013 / Revised: 20 June 2013 / Accepted: 13 July 2013 / Published online: 8 August 2013

(C) The Author(s) 2013. This article is published with open access at Springerlink.com

\begin{abstract}
The present paper accounts for the synthesis, crystal structure, differential scanning calorimetry, vibrational study, and electrical properties of the $\left.\left[\mathrm{N}_{(} \mathrm{C}_{3} \mathrm{H}_{7}\right)_{4}\right]_{2} \mathrm{Zn}_{2} \mathrm{Cl}_{6}$ compound. The latter is crystallized at room temperature in the triclinic system $(P \overline{1}$ space group) with the following unit cell parameters: $a=13.736(2) \AA, b=17.044(3) \AA, c=17.334(2) \AA$, $\alpha=68.30(2)^{\circ}, \beta=75.14(2)^{\circ}$, and $\gamma=84.93(3)$. The atomic arrangement can be described by alternating organic and inorganic layers parallel to the (001) plan, made up of $\left[\mathrm{N}\left(\mathrm{C}_{3} \mathrm{H}_{7}\right)_{4}\right]^{+}$ groups and $\left[\mathrm{Zn}_{2} \mathrm{Cl}_{6}\right]^{2-}$ dimers, respectively. In crystal structure, the inorganic layer, built up by $\mathrm{Zn}_{2} \mathrm{Cl}_{6}$ dimers, is connected to the organic ones through van der Waals interaction in order to build cation-anion-cation cohesion. The infrared and Raman studies confirm the presence of the organic group tetrapropylammonium and the $\mathrm{Zn}_{2} \mathrm{Cl}_{6}$ anion. Concerning the differential scanning calorimetry, it revealed two reversible solid-solid phase transitions of first order: at $327 / 324 \mathrm{~K}$ and $347 / 343 \mathrm{~K}$ (heating/cooling). Besides, the impedance spectroscopy study, reported in the sample, reveals that the conduction in the material is due to a hopping process. Regarding the temperature dependence of the dc conductivity, it suggests Arrhenius type: $\sigma_{\mathrm{dc}} T=B \exp \left(-E_{a} / k T\right)$. The tetrapropylammonium cations appeared to be the most sensitive to the phase transition.
\end{abstract}

M. B. Gzaiel $(\varangle) \cdot$ A. Oueslati $\cdot$ I. Chaabane $\cdot$ F. Hlel $\cdot$ M. Gargouri Laboratoire de l'état solide, Faculté des Sciences de Sfax, B.P. 802, 3018 Sfax, Tunisia

e-mail: bengzaiel_malika@yahoo.com

A. Bulou

CNRS UMR 6283, Institut des Molécules et Matériaux du Mans (IMMM), LUNAM Université, Université du Maine,

Avenue Olivier Messiaen, 72085 Le Mans Cedex 9, France
Keywords Organic-inorganic hybrid material $\cdot$ Crystal structure $\cdot$ Phase transition - Raman spectroscopy · Electrical properties

\section{Introduction}

The prospect of creating new functional materials with tunable properties gives a strong motivation on the research of organic-inorganic hybrids $[1,2]$. Interest in these compounds has grown due to their remarkable structural and physical properties like ferro-electricity, ferro-elasticity, and low-dimensional magnetism [3-5]. The synthesis of low-dimensional mixed organicinorganic materials enables both inorganic and organic components on the molecular scale to be optimized and thus to exhibit specific properties, such as electronic, catalytic, optical, and second-order non-linear optical [6-9] ones. On the other hand, the compounds crystallized with aliphatic tetra-ammonium cations with the general formula $\left(\mathrm{C}_{\mathrm{n}} \mathrm{H}_{2 \mathrm{n}+1}\right)_{4} \mathrm{~N}^{+}$, such as $\left(\mathrm{CH}_{3}\right)_{4} \mathrm{~N}^{+}$, $\left(\mathrm{C}_{2} \mathrm{H}_{5}\right)_{4} \mathrm{~N}^{+}$, and $\left(\mathrm{C}_{3} \mathrm{H}_{7}\right)_{4} \mathrm{~N}^{+}$, undergo many structural phase transitions governed by the reorientational dynamics of the tetraalkyl-ammonium groups [10]. That is why we are interested, in our laboratory, in the investigation of the physical properties of hybrid materials with quaternary ammonium cation with the general formula $\left(\mathrm{C}_{\mathrm{n}} \mathrm{H}_{2 \mathrm{n}+1}\right)_{4} \mathrm{~N}^{+}$. Such properties related to cation with $\mathrm{n}=1$ and 2 were well stabilized $[11,12]$. In the case of a long chain (n>2), only $\left[\mathrm{N}\left(\mathrm{C}_{3} \mathrm{H}_{7}\right)_{4}\right]_{2} \mathrm{Cu}_{2} \mathrm{Cl}_{6}, \quad\left[\mathrm{~N}\left(\mathrm{C}_{3} \mathrm{H}_{7}\right)_{4}\right]_{2} \mathrm{Cd}_{2} \mathrm{Cl}_{6}$, $\left[\mathrm{N}\left(\mathrm{C}_{3} \mathrm{H}_{7}\right)_{4}\right]_{2} \mathrm{Hg}_{2} \mathrm{Cl}_{6}$, and $\left[\mathrm{N}\left(\mathrm{C}_{4} \mathrm{H}_{9}\right)_{4}\right]_{2} \mathrm{Cu}_{2} \mathrm{Cl}_{6}$ structure are reported $[11,13-15]$.

The present work reports the synthesis, crystal structure, thermal analysis, vibrational study, and electrical properties of the bis tetrapropylammonium hexachloro-dizincate. 


\section{Experimental section}

Synthesis

$\mathrm{ZnCl}_{2}$ (purity $98 \%$; FLUKA) and $\left[\mathrm{N}\left(\mathrm{C}_{3} \mathrm{H}_{7}\right)_{4}\right] \mathrm{Cl}$ (purity $97 \%$; FLUKA) were dissolved in a $\mathrm{HCl}(1 \mathrm{M})$ aqueous solution in a molar ratio of $1: 1$. Colorless prismatic monocrystals of $\left[\mathrm{N}\left(\mathrm{C}_{3} \mathrm{H}_{7}\right)_{4}\right]_{2} \mathrm{Zn}_{2} \mathrm{Cl}_{6}$ compound were obtained by slow evaporation at room temperature. The single crystal was selected by using a microscope. After that, it has been washed by absolute ethanol and dried in vacuum desiccators 2 days before the measurements.

The reactions sequence for the synthesis is shown in the following equation:

$2\left[\mathrm{~N}\left(\mathrm{C}_{3} \mathrm{H}_{7}\right)_{4}\right] \mathrm{Cl}+2 \mathrm{ZnCl}_{2} \stackrel{\mathrm{HCl}(1 \mathrm{M})}{\longrightarrow}\left[\left(\mathrm{C}_{3} \mathrm{H}_{7}\right)_{4} \mathrm{~N}\right]_{2} \mathrm{Zn}_{2} \mathrm{Cl}_{6}$

Crystal structure

X-ray data were collected at $298 \mathrm{~K}$ on colorless prismatic crystal of dimensions $0.35 \times 0.23 \times 0.06 \mathrm{~mm}^{3}$ using a Bruker AXS CCD area detector diffractometer, with $\mathrm{MoK} \alpha$ radiation $(\lambda=0.71073 \AA)$, in $\varphi$ and $\omega$ scans mode. For unit cell refinement, 20,522 reflections with $\theta$ ranging from $1.3^{\circ}$ to $30.5^{\circ}$ were used. The crystal structure adopts a triclinic system with $P \overline{1}$ space group $(\mathrm{Z}=4)$. Absorption corrections were based on multiple and symmetry-equivalent reflections in the data set using the SADABS program [16]. The structure was solved by Patterson methods using SHELXS 97 [17] and refined by least squares techniques with Crystals 2003 [18]. Anisotropic thermal parameters were employed for non-hydrogen atoms. With regard to the hydrogen atoms attached to carbon atoms, they were positioned geometrically, and initially refined with soft restraints on the bond lengths and angles to regularize their geometry, $\mathrm{C}-\mathrm{H}$ in the range of $0.93-0.98 \AA$. Diamond computer program [19] was used to prepare drawings. The crystal data, collected reflections, and parameters of the final refinement are reported in Table 1. Interatomic bond distances and angles schemes are listed in Tables 2 and 3. It is worthwhile to mention that atomic coordinates anisotropic displacement parameters, tables for all bond distances, and angles have been deposited at the Cambridge Crystallographic Data Center (deposition number CCDC 861352).

\section{Characterization}

With respect to the calorimetric measurements, they were performed on Perkin Elmer DSC-7 from 293 up to $473 \mathrm{~K}$ at an average heating of $5^{\circ} \mathrm{C} / \mathrm{min}$ with $12 \mathrm{mg}$ sample weight.
Table 1 Crystal data and structure refinement for $\left[\mathrm{N}\left(\mathrm{C}_{3} \mathrm{H}_{7}\right)_{4}\right]_{2} \mathrm{Zn}_{2} \mathrm{Cl}_{6}$

\begin{tabular}{|c|c|}
\hline Formula & {$\left[\mathrm{N}\left(\mathrm{C}_{3} \mathrm{H}_{7}\right)_{4}\right]_{2} \mathrm{Zn}_{2} \mathrm{Cl}_{6}$} \\
\hline Molecular weight $\left(\mathrm{g} \mathrm{mol}^{-1}\right)$ & 716.2184 \\
\hline Color/shape & Prismatic, colorless \\
\hline Space group & $\mathrm{P} \overline{1}$ \\
\hline Crystal system & Triclinic \\
\hline Temperature (K) & $298(2)$ \\
\hline \multicolumn{2}{|l|}{ Unit cell dimensions } \\
\hline$a(\AA)$ & $13.736(2)$ \\
\hline$b(\AA)$ & $17.044(3)$ \\
\hline$c(\AA)$ & $17.334(2)$ \\
\hline$\alpha\left(^{\circ}\right)$ & $68.30(2)$ \\
\hline$\beta\left(^{\circ}\right)$ & $75.14(2)$ \\
\hline$\gamma\left({ }^{\circ}\right)$ & $84.93(3)$ \\
\hline Volume $\left(\AA^{3}\right)$ & $3,644.5(5)$ \\
\hline$Z$ & 4 \\
\hline Absorption coefficient $\left(\mathrm{mm}^{-1}\right)$ & 1.771 \\
\hline$\rho_{\text {calc. }}\left(\mathrm{g} / \mathrm{cm}^{3}\right)$ & 1.31 \\
\hline Radiation type, $\lambda(\AA)$ & $\mathrm{MoK}_{\alpha}, 0.71073$ \\
\hline Crystal size $\left(\mathrm{mm}^{3}\right)$ & $0.35 \times 0.23 \times 0.06$ \\
\hline$\theta$ range $\left(^{\circ}\right)$ & $1.3 \leq \theta \leq 30.5$ \\
\hline Range of h, k, 1 & $-18 \rightarrow 19,-21 \rightarrow 24,0 \rightarrow 23$ \\
\hline Measured reflections & 31,625 \\
\hline Independent reflections & 20,522 \\
\hline Reflections $>3 \sigma(\mathrm{I})$ & 7,628 \\
\hline$R_{\text {int }}$ & 0.028 \\
\hline Refinement on & $\mathrm{F}^{2}$ \\
\hline Restraints/parameters & $0 / 614$ \\
\hline Goodness of fit & 0.947 \\
\hline $\mathrm{R} / \mathrm{wR}$ & $0.04 / 0.06$ \\
\hline$\Delta \rho(\max ) / \Delta \rho(\min )\left(\mathrm{e} \AA^{-3}\right)$ & $0.39 /-0.37$ \\
\hline
\end{tabular}

The infrared spectrum was obtained using a Perkin-Elmer FT-IR 1000 spectrometer with a sample pressed in KBr pellet in the $400-4,000 \mathrm{~cm}^{-1}$ region. The Raman spectra of the sample were obtained under microscope with a T-64000 Raman spectrometer (ISA, Jobin Yvon) with nitrogen-cooled $\mathrm{CCD}$ detector. The spectra were registered in triple subtractive mode with $1,800 \mathrm{tr} / \mathrm{mm}$ grating from 50 to $3,500 \mathrm{~cm}^{-1}$.

\section{Electrical measurements}

The electrical measurements were performed using a twoelectrode configuration. In fact, the $\left[\left(\mathrm{C}_{3} \mathrm{H}_{7}\right)_{4} \mathrm{~N}\right]_{2} \mathrm{Zn}_{2} \mathrm{Cl}_{6}$ sample was pressed into pellets of $8 \mathrm{~mm}$ in diameter and $1.1 \mathrm{~mm}$ in thickness using $3 \mathrm{t} / \mathrm{cm}^{2}$ uniaxial pressures. The ac impedance data, $|Z|$, and phase angle were obtained in the frequency range $209 \mathrm{~Hz}-5 \mathrm{MHz}$ using TEGAM 3550 impedance analyzer over the temperature range $303-403 \mathrm{~K}$. 
Table 2 Principal intermolecular distances $(\AA)$ and angles $\left(^{\circ}\right)$ for anionic part $\left[\mathrm{Zn}_{2} \mathrm{Cl}_{6}\right]^{2-}$

\begin{tabular}{|c|c|c|c|}
\hline \multicolumn{2}{|c|}{ Bond lengths $(\AA)$} & \multicolumn{2}{|l|}{ Angles $\left(^{\circ}\right)$} \\
\hline $\mathrm{Zn}_{2} \mathrm{Cl}_{6}(1)$ & $2.341(15)$ & ClL1-Zn1-CIL2 & $92.24(5)$ \\
\hline $\mathrm{Zn} 1-\mathrm{ClL} 1$ & $2.3598(15)$ & ClL1-Zn1-C111 & $114.07(7)$ \\
\hline Zn1-CIL2 & $2.2120(16)$ & ClL2-Zn1-C111 & $109.42(6)$ \\
\hline $\mathrm{Zn} 1-\mathrm{Cl11}$ & $2.2057(16)$ & ClL1-Zn1-C112 & $109.41(7)$ \\
\hline $\mathrm{Zn} 1-\mathrm{Cl1} 2$ & $2.3502(15)$ & ClL2-Zn1-Cl12 & $115.57(7)$ \\
\hline $\mathrm{Zn}_{2} \mathrm{Cl}_{6}(2)$ & 2.3547 & Cl11-Zn1-C112 & $114.28(7)$ \\
\hline Zn2-ClL1 & $2.2093(17)$ & ClL1-Zn2-ClL2 & $92.15(5)$ \\
\hline $\mathrm{Zn} 2-\mathrm{ClL} 2$ & $2.2052(18)$ & $\mathrm{ClL} 1-\mathrm{Zn} 2-\mathrm{Cl} 21$ & $112.93(7)$ \\
\hline $\mathrm{Zn} 2-\mathrm{Cl} 21$ & $2.3587(14)$ & ClL2-Zn2-Cl21 & $110.87(7)$ \\
\hline $\mathrm{Zn} 2-\mathrm{Cl} 22$ & $2.3433(15)$ & $\mathrm{ClL} 1-\mathrm{Zn} 2-\mathrm{Cl} 22$ & $109.21(7)$ \\
\hline $\mathrm{Zn}_{2} \mathrm{Cl}_{6}(3)$ & $2.2133(16)$ & ClL2-Zn2-Cl22 & $115.60(7)$ \\
\hline $\mathrm{Zn} 3-\mathrm{ClL} 3^{\mathrm{ii}}$ & $2.2043(16)$ & $\mathrm{Cl} 21-\mathrm{Zn} 2-\mathrm{Cl} 22$ & $114.14(8)$ \\
\hline $\mathrm{Zn} 3-\mathrm{ClL}^{\mathrm{i}}$ & $2.3546(15)$ & $\mathrm{Zn} 2-\mathrm{ClL} 1-\mathrm{Zn} 1$ & $87.95(5)$ \\
\hline $\mathrm{Zn} 3-\mathrm{Cl} 12$ & $2.3435(14)$ & $\mathrm{Zn} 1-\mathrm{ClL} 2-\mathrm{Zn} 2$ & $87.41(5)$ \\
\hline Zn3-C111 & $2.2123(16)$ & CIL3-Zn3-CIL3 & $92.34(5)$ \\
\hline $\mathrm{Zn}_{2} \mathrm{Cl}_{6}(4)$ & $2.2156(16)$ & $\mathrm{ClL} 3-\mathrm{Zn} 3-\mathrm{Cl1} 2^{\mathrm{ii}}$ & $112.88(6)$ \\
\hline $\mathrm{Zn} 4-\mathrm{ClL} 4^{\mathrm{ii}}$ & & $\mathrm{ClL} 3-\mathrm{Zn} 3-\mathrm{Cl1} 2^{\mathrm{i}}$ & $110.94(6)$ \\
\hline $\mathrm{Zn} 4-\mathrm{ClL} 4^{\mathrm{i}}$ & & ClL3-Zn3-C111 ${ }^{\mathrm{ii}}$ & $112.15(7)$ \\
\hline $\mathrm{Zn} 4-\mathrm{ClL} 21$ & & ClL3-Zn3-C111 ${ }^{\mathrm{i}}$ & $113.26(7)$ \\
\hline \multirow[t]{7}{*}{ Zn4-ClL22 } & & Cl12-Zn3-Cl11 & $115.12(7)$ \\
\hline & & CIL4-Zn4-CIL4 & $91.40(5)$ \\
\hline & & CIL4-Zn4-CIL $21^{\mathrm{ii}}$ & $112.60(6)$ \\
\hline & & ClL4-Zn4-CIL2 $1^{\mathrm{i}}$ & $115.35(7)$ \\
\hline & & CIL4-Zn4-CIL22 $2^{\mathrm{ii}}$ & $111.92(6)$ \\
\hline & & CIL4-Zn4-CIL22 ${ }^{\mathrm{i}}$ & $108.62(6)$ \\
\hline & & CIL21-Zn4-ClL22 & 114.71(7) \\
\hline
\end{tabular}

Symmetry codes: $i \mathrm{x}, \mathrm{y}, \mathrm{z} ; i i-\mathrm{x},-\mathrm{y},-\mathrm{z}$

\section{Results and discussion}

Structure description

The crystallographic analysis of this compound reveals that the crystal structure of $\left[\left(\mathrm{C}_{3} \mathrm{H}_{7}\right)_{4} \mathrm{~N}\right]_{2} \mathrm{Zn}_{2} \mathrm{Cl}_{6}$ consists of one and two half of $\left[\mathrm{Zn}_{2} \mathrm{Cl}_{6}\right]^{2-}$ un-equivalent dimers and four $\left[\mathrm{N}\left(\mathrm{C}_{3} \mathrm{H}_{7}\right)_{4}\right]^{+}$ cations. A view of the asymmetric unit of the structure showing the thermal ellipsoid atoms mean square displacements of nonhydrogen is depicted in Fig. 1. The structural arrangement of the title compound can be described as an alternation of organic and inorganic layers parallel to the (001) plan, made up of $\left[\mathrm{N}\left(\mathrm{C}_{3} \mathrm{H}_{7}\right)_{4}\right]^{+}$groups and $\left[\mathrm{Zn}_{2} \mathrm{Cl}_{6}\right]^{2-}$ dimers, respectively (Fig. 2). This figure shows that cations are stacked in a regularly cross form and orient their ramifications toward $\mathrm{ZnCl}_{4}$ tetrahedra of four adjacent dimers localized in two successive inorganic sheets. The compound crystallizes in the centrosymmetric triclinic space group $P \overline{1}$. Regarding the organic layers, they are formed by two alternating infinite chains parallel to the $b$ direction. Each chain is made up of two alternative unequivalent cations; one is in trans or the other in gauche configurations (Fig. 3).

The atoms of all organic cations occupy general positions with $\mathrm{C} 1$ point group symmetry. In the fourth cations, $\mathrm{C}-\mathrm{C}-\mathrm{C}$, $\mathrm{C}-\mathrm{N}-\mathrm{C}$, and $\mathrm{N}-\mathrm{C}-\mathrm{C}$ angles and $\mathrm{C}-\mathrm{C}$ and $\mathrm{C}-\mathrm{N}$ distances
Table 3 Principal intermolecular distances $(\AA)$ and angles $\left(^{\circ}\right)$ for cationic part $\left[\mathrm{N}\left(\mathrm{C}_{3} \mathrm{H}_{7}\right)_{4}\right]^{+}$

\begin{tabular}{|c|c|c|c|}
\hline \multicolumn{2}{|l|}{ Bond lengths $(\AA)$} & \multicolumn{2}{|l|}{ Angles $\left(^{\circ}\right)$} \\
\hline$\left[\mathrm{N}(1)\left(\mathrm{C}_{3} \mathrm{H}_{7}\right)_{4}\right]^{+}$ & $1.516(5)$ & $\mathrm{C} 11-\mathrm{N} 1-\mathrm{C} 12$ & $111.4(4)$ \\
\hline $\mathrm{N} 1-\mathrm{C} 11$ & $1.513(6)$ & C11-N1-C13 & $108.8(4)$ \\
\hline $\mathrm{N} 1-\mathrm{C} 12$ & $1.513(6)$ & C12-N1-C13 & 109.1(4) \\
\hline N1-C13 & $1.526(6)$ & C11-N1-C14 & 108.4(4) \\
\hline $\mathrm{N} 1-\mathrm{C} 14$ & $1.506(7)$ & C12-N1-C14 & $107.7(3)$ \\
\hline $\mathrm{C} 11-\mathrm{C} 15$ & $1.501(7)$ & C13-N1-C14 & $111.6(4)$ \\
\hline C15-C19 & $1.503(7)$ & $\mathrm{N} 1-\mathrm{C} 11-\mathrm{C} 15$ & $116.2(4)$ \\
\hline C12-C16 & $1.516(7)$ & C11-C15-C19 & $109.9(5)$ \\
\hline C16-C110 & $1.509(7)$ & $\mathrm{N} 1-\mathrm{C} 12-\mathrm{C} 16$ & $116.1(4)$ \\
\hline C13-C17 & $1.522(7)$ & $\mathrm{C} 12-\mathrm{C} 16-\mathrm{C} 110$ & $109.8(5)$ \\
\hline C17-C111 & $1.502(7)$ & $\mathrm{N} 1-\mathrm{C} 13-\mathrm{C} 17$ & $115.9(4)$ \\
\hline $\mathrm{C} 14-\mathrm{C} 18$ & $1.532(8)$ & C13-C17-C111 & $109.4(5)$ \\
\hline C18-C112 & $1.522(6)$ & $\mathrm{N} 1-\mathrm{C} 14-\mathrm{C} 18$ & $116.8(4)$ \\
\hline$\left[\mathrm{N}(2)\left(\mathrm{C}_{3} \mathrm{H}_{7}\right)_{4}\right]^{+}$ & $1.524(6)$ & C14-C18-C112 & $107.8(5)$ \\
\hline $\mathrm{N} 2-\mathrm{C} 23$ & $1.511(6)$ & $\mathrm{C} 23-\mathrm{N} 2-\mathrm{C} 21$ & $111.5(4)$ \\
\hline N2-C21 & $1.519(5)$ & $\mathrm{C} 23-\mathrm{N} 2-\mathrm{C} 22$ & $111.6(4)$ \\
\hline $\mathrm{N} 2-\mathrm{C} 22$ & $1.513(6)$ & $\mathrm{C} 21-\mathrm{N} 2-\mathrm{C} 22$ & $105.6(3)$ \\
\hline N2-C24 & $1.523(7)$ & $\mathrm{C} 23-\mathrm{N} 2-\mathrm{C} 24$ & $105.6(3)$ \\
\hline $\mathrm{C} 23-\mathrm{C} 27$ & $1.504(7)$ & $\mathrm{C} 21-\mathrm{N} 2-\mathrm{C} 24$ & $111.4(4)$ \\
\hline $\mathrm{C} 27-\mathrm{C} 211$ & $1.512(7)$ & $\mathrm{C} 22-\mathrm{N} 2-\mathrm{C} 24$ & $111.3(4)$ \\
\hline $\mathrm{C} 21-\mathrm{C} 25$ & $1.505(7)$ & $\mathrm{N} 2-\mathrm{C} 23-\mathrm{C} 27$ & $115.9(4)$ \\
\hline $\mathrm{C} 25-\mathrm{C} 29$ & $1.532(7)$ & C23-C27-C211 & $108.6(4)$ \\
\hline $\mathrm{C} 22-\mathrm{C} 26$ & $1.508(7)$ & $\mathrm{N} 2-\mathrm{C} 21-\mathrm{C} 25$ & $115.7(4)$ \\
\hline $\mathrm{C} 26-\mathrm{C} 210$ & $1.509(7)$ & $\mathrm{C} 21-\mathrm{C} 25-\mathrm{C} 29$ & $109.8(5)$ \\
\hline C24-C28 & $1.506(6)$ & $\mathrm{N} 2-\mathrm{C} 22-\mathrm{C} 26$ & $116.9(4)$ \\
\hline $\mathrm{C} 28-\mathrm{C} 212$ & $1.515(6)$ & $\mathrm{C} 22-\mathrm{C} 26-\mathrm{C} 210$ & $108.8(5)$ \\
\hline$\left[\mathrm{N}(3)\left(\mathrm{C}_{3} \mathrm{H}_{7}\right)_{4}\right]^{+}$ & $1.520(6)$ & $\mathrm{N} 2-\mathrm{C} 24-\mathrm{C} 28$ & $115.4(4)$ \\
\hline N3-C31 & $1.522(6)$ & $\mathrm{C} 24-\mathrm{C} 28-\mathrm{C} 212$ & $109.9(5)$ \\
\hline N3-C32 & $1.503(7)$ & C31-N3-C32 & $108.6(4)$ \\
\hline N3-C33 & $1.509(7)$ & $\mathrm{C} 31-\mathrm{N} 3-\mathrm{C} 33$ & 108.7(4) \\
\hline N3-C34 & $1.503(7)$ & C32-N3-C33 & $111.0(4)$ \\
\hline C31-C35 & $1.525(8)$ & C31-N3-C34 & $111.4(4)$ \\
\hline C35-C39 & $1.486(7)$ & C32-N3-C34 & $109.3(4)$ \\
\hline C32-C36 & $1.504(8)$ & C33-N3-C34 & $107.8(4)$ \\
\hline C36-C310 & $1.489(7)$ & N3-C31-C35 & $116.5(5)$ \\
\hline C33-C37 & $1.504(8)$ & C31-C35-C39 & $109.9(5)$ \\
\hline C37-C311 & $1.521(6)$ & N3-C32-C36 & $116.4(5)$ \\
\hline C34-C38 & $1.519(6)$ & C $32-\mathrm{C} 36-\mathrm{C} 310$ & $110.3(5)$ \\
\hline C38-C312 & $1.512(6)$ & N3-C33-C37 & $117.4(4)$ \\
\hline$\left[\mathrm{N}(4)\left(\mathrm{C}_{3} \mathrm{H}_{7}\right)_{4}\right]^{+}$ & $1.520(6)$ & C33-C37-C311 & $109.8(5)$ \\
\hline $\mathrm{N} 4-\mathrm{C} 41$ & $1.493(7)$ & N3-C34-C38 & $116.5(5)$ \\
\hline N4-C42 & $1.518(8)$ & C34-C38-C312 & $110.7(6)$ \\
\hline N4-C44 & $1.508(7)$ & C41-N4-C42 & $106.2(4)$ \\
\hline $\mathrm{N} 4-\mathrm{C} 43$ & $1.515(7)$ & C41-N4-C44 & $111.4(4)$ \\
\hline $\mathrm{C} 41-\mathrm{C} 45$ & $1.514(7)$ & C42-N4-C44 & $111.4(4)$ \\
\hline C45-C49 & $1.503(7)$ & C41-N4-C43 & 111.1(4) \\
\hline $\mathrm{C} 42-\mathrm{C} 46$ & $1.497(7)$ & $\mathrm{C} 42-\mathrm{N} 4-\mathrm{C} 43$ & 111.1(4) \\
\hline C46-C410 & $1.528(7)$ & $\mathrm{C} 44-\mathrm{N} 4-\mathrm{C} 43$ & 105.7(4) \\
\hline $\mathrm{C} 44-\mathrm{C} 48$ & & N4-C41-C45 & $116.2(4)$ \\
\hline C48-C412 & & C41-C45-C49 & $110.6(5)$ \\
\hline $\mathrm{C} 43-\mathrm{C} 47$ & & $\mathrm{~N} 4-\mathrm{C} 42-\mathrm{C} 46$ & $115.4(4)$ \\
\hline C47-C411 & & $\mathrm{C} 42-\mathrm{C} 46-\mathrm{C} 410$ & $110.1(5)$ \\
\hline & & $\mathrm{N} 4-\mathrm{C} 44-\mathrm{C} 48$ & $116.0(4)$ \\
\hline & & C44-C48-C412 & $110.5(5)$ \\
\hline & & $\mathrm{N} 4-\mathrm{C} 43-\mathrm{C} 47$ & $117.1(4)$ \\
\hline & & C43-C47-C411 & $108.5(5)$ \\
\hline
\end{tabular}

(Table 3) are commonly observed [20]. Two inorganic layers are observed at $\mathrm{z}=0$ and $\mathrm{z}=1 / 2$, the first of which is made up 

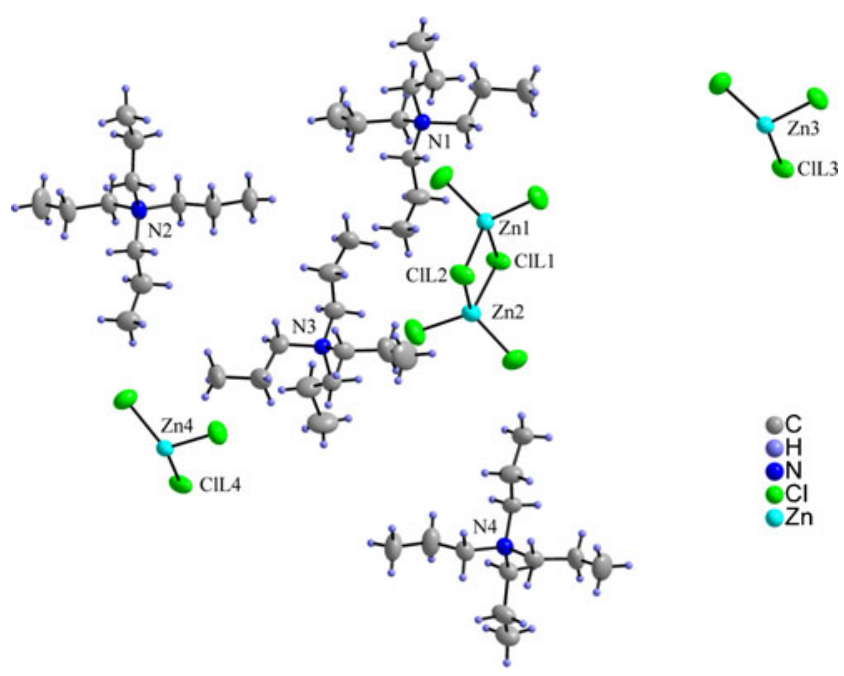

Fig. 1 ORTEP representation of asymmetric unit with $50 \%$ probability of the thermal ellipsoid of non-hydrogen atoms of $\left[\mathrm{N}\left(\mathrm{C}_{3} \mathrm{H}_{7}\right)_{4}\right]_{2} \mathrm{Zn}_{2} \mathrm{Cl}_{6}$

of two un-equivalent $\mathrm{Zn}_{2} \mathrm{Cl}_{6}$ dimers. Not only is each anion built up by two $\mathrm{ZnCl}_{4}$ tetrahedra generated by inversion center but also shares one bridging chlorine atom (CIL3 and CIL4). In both anions, bridging chlorine and zinc atoms $(\mathrm{Zn} 3, \mathrm{Zn} 4)$ are planar. As for the second layer, it is composed of one $\mathrm{Zn}_{2} \mathrm{Cl}_{6}$ dimers built up by two $\mathrm{ZnCl}_{4}$ tetrahedra sharing two bridging chlorine atoms (CIL1 and CIL2), whereas in the latter dimers, bridging chlorine and zinc atoms $(\mathrm{Zn} 1, \mathrm{Zn} 2)$ are pseudo-planar with distortion angle equal to $3.87(3)^{\circ}$. The $\mathrm{Zn}_{2} \mathrm{Cl}_{6}$ dimers can be described as two strongly distorted $\mathrm{ZnCl}_{4}$ tetrahedra, commonly observed in $\mathrm{M}_{2} \mathrm{X}_{6}$ groups [11, 13]. Two types of ligands are usually mentioned, $\mathrm{XE}$ (external) and XL (linkage). Moreover, bibliographic investigations show that $\mathrm{M}-\mathrm{X}$ distances and $\mathrm{X}-\mathrm{M}-\mathrm{X}$ angles verify $(\mathrm{M}-\mathrm{XL}>\mathrm{M}-\mathrm{XE})$ (I) and $(\mathrm{XL}-\mathrm{M}-\mathrm{XE}$, and $\mathrm{XE}-\mathrm{M}-\mathrm{XE}$ are generally bigger than XL-M-XL) (II) [21]. The geometry of $\mathrm{Zn}_{2} \mathrm{Cl}_{6}$ dimers verifies the reported relations (Table 2). For all $\mathrm{Zn}_{2} \mathrm{Cl}_{6}$ anions, $\mathrm{ClL}-\mathrm{Zn}-\mathrm{ClL}-\mathrm{Zn}$ are pseudo-square with a weak out-of-plan distortion in dimers observed in the second

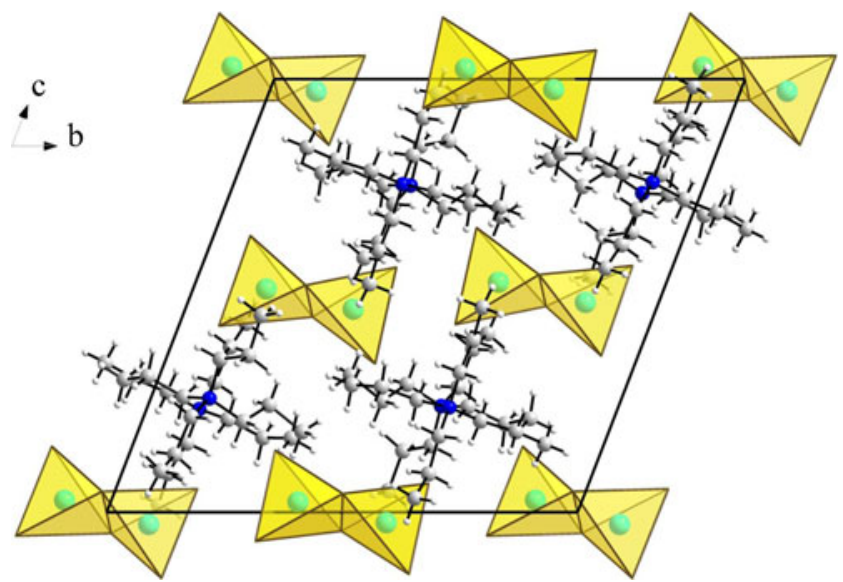

Fig. $2\left[\begin{array}{lll}0 & 0 & 1\end{array}\right]$ view showing alternation of organic and inorganic sheets of $\left[\mathrm{N}\left(\mathrm{C}_{3} \mathrm{H}_{7}\right)_{4}\right]_{2} \mathrm{Zn}_{2} \mathrm{Cl}_{6}$

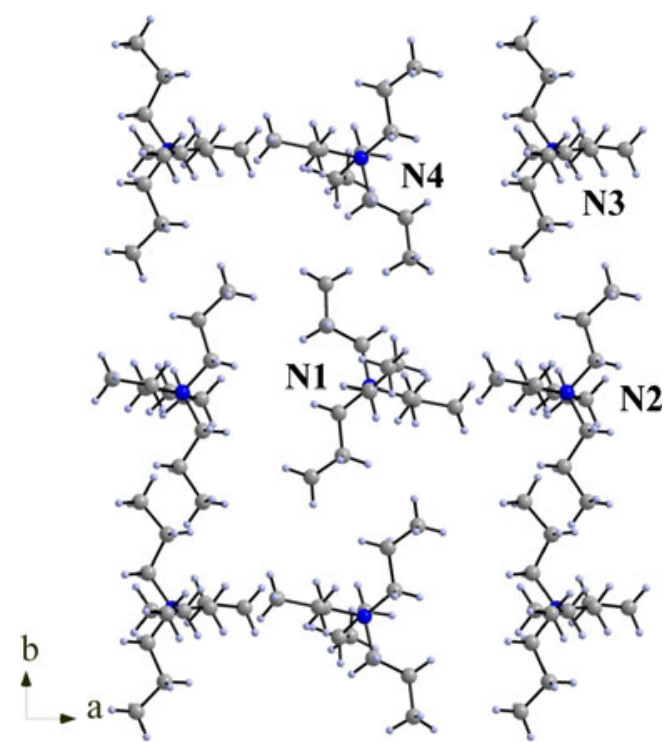

Fig. 3 View of an organic layer showing the alternating of two infinite organic chains parallel to $b$ direction of $\left[\mathrm{N}\left(\mathrm{C}_{3} \mathrm{H}_{7}\right)_{4}\right]_{2} \mathrm{Zn}_{2} \mathrm{Cl}_{6}$

inorganic sheets. These results are in agreement with the above comparison (I and II). Taking into account the geometrical characteristics of the entities and considering the calculated average values of the Baur distortion indices (DI) [22]

$$
\begin{aligned}
\mathrm{ID}(Z n-\mathrm{Cl}) & =\sum_{i=1}^{4} \frac{\left|Z n-\mathrm{Cl}_{i}-Z n-\mathrm{Cl}_{m}\right|}{4\left(Z n-\mathrm{Cl}_{m}\right)} ; \\
\mathrm{ID}(\mathrm{ClZnCl}) & =\sum_{i=1}^{6} \frac{\left|\mathrm{ClZnCl}_{i}-\mathrm{ClZnCl}_{m}\right|}{6\left(\mathrm{Cl} Z n \mathrm{Cl}_{m}\right)}
\end{aligned}
$$

where $m$ signifies the mean value for the polyhedron.

$\{\mathrm{ID} \mathrm{Zn}(1)-\mathrm{Cl}=0.031$, ID $\mathrm{Zn}(2)-\mathrm{Cl}=0.032$, ID $\mathrm{Zn}(3)-$ $\mathrm{Cl}=0.033$, and $\mathrm{ID} \mathrm{Zn}(4)-\mathrm{Cl}=0.030\}$, we can deduce that the $\mathrm{ZnCl}_{4}$ tetrahedra are more distorted in the $\mathrm{Zn}_{2} \mathrm{Cl}_{6}$ observed in the second inorganic sheets in the dimers formed by $\mathrm{Zn}(3) \mathrm{Cl}_{4}$ tetrahedron than in $\mathrm{Zn}_{2} \mathrm{Cl}_{6}$ made up of $\mathrm{Zn}(4) \mathrm{Cl}_{4}$.

\section{Calorimetric study}

The order of the phase transition (first or second order) may be determined by analyzing the shape of the heat anomaly and value of the temperature hysteresis in the calorimetric measurements. The values of the thermal hysteresis in our experiment were estimated from linear extrapolation to the scanning rate. On the other hand, the character of the phase transition (order-disorder or displacive) is classified on the basis of the value of the entropy effect.

Figure $4 \mathrm{a}$ and $\mathrm{b}$ shows the DSC runs for $\left[\mathrm{N}\left(\mathrm{C}_{3} \mathrm{H}_{7}\right)_{4}\right]_{2} \mathrm{Zn}_{2} \mathrm{Cl}_{6}$ upon the heating and cooling of $5{ }^{\circ} \mathrm{C} / \mathrm{min}$. An overview of the 
(a)

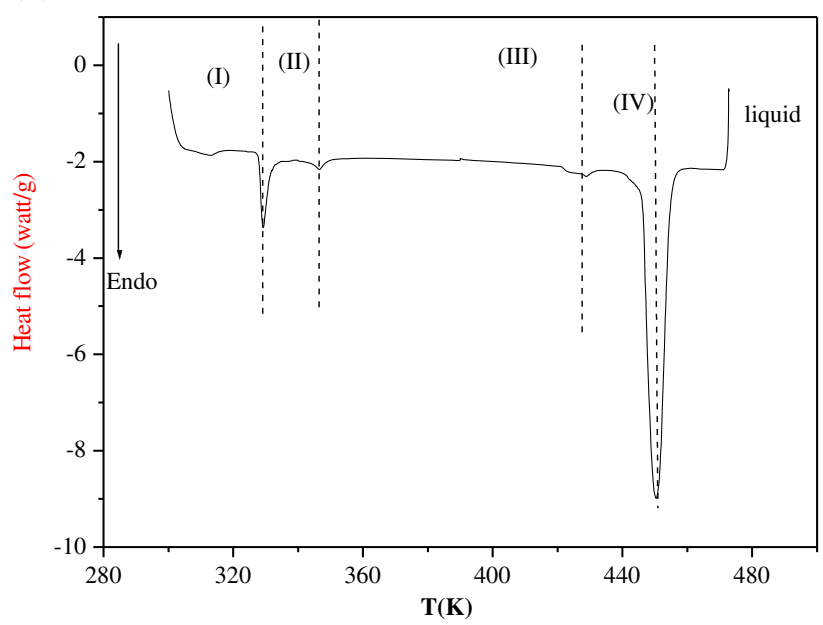

(b)

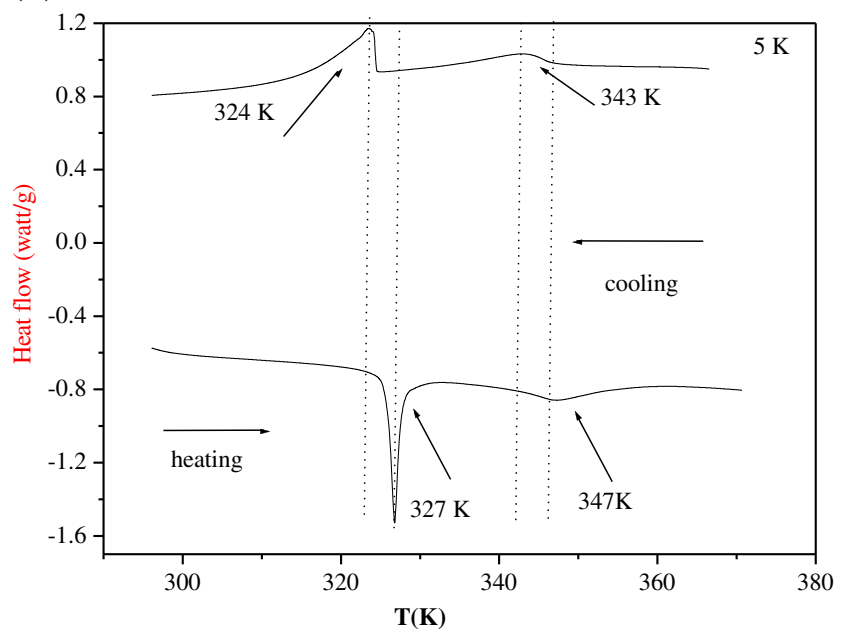

Fig. 4 Differential scanning calorimetry analysis of $\left[\mathrm{N}\left(\mathrm{C}_{3} \mathrm{H}_{7}\right)_{4}\right]_{2} \mathrm{Zn}_{2} \mathrm{Cl}_{6}$ compound

results unambiguously illustrates the existence of three endothermic solid-solid phase transitions that define four successive phases on heating, denoted by I, II, III, and IV, respectively. The parameters characterizing these phase transitions are summarized in Table 4.

Figure $4 \mathrm{~b}$ clearly shows that slightly above room temperature, the compound undergoes two reversible phase transitions

Table 4 Phase transitions in $\left[\mathrm{N}\left(\mathrm{C}_{3} \mathrm{H}_{7}\right)_{4}\right]_{2} \mathrm{Zn}_{2} \mathrm{Cl}_{6}$

\begin{tabular}{llllll}
\hline Phases & $T_{\mathrm{h}}(\mathrm{K})$ & $T_{\mathrm{c}}(\mathrm{K})$ & $\Delta T(\mathrm{~K})$ & $\Delta \mathrm{S}\left(\mathrm{J} \mathrm{g}^{-1} \mathrm{k}^{-1}\right)$ & $\Delta \mathrm{H}\left(\mathrm{J} \mathrm{g}^{-1}\right)$ \\
\hline I II & 327 & 324 & 3 & 0.15 & 50.00 \\
II III & 347 & 343 & 4 & 0.04 & 13.15 \\
III IV & 429 & & & 0.01 & 4.20 \\
Melting & 451 & & & 0.16 & 74.47
\end{tabular}

$T_{h}, T_{c}$ temperature of the phase transitions upon heating and cooling, $\Delta S$ entropies, $\Delta H$ enthalpies
(PT). Extrapolated to zero scanning rate, the transition between phase I and phase II occurs at $T_{1}=327 / 324 \mathrm{~K}$ (heating/cooling cycle) and its significant temperature hysteresis $(\Delta T=3 \mathrm{~K})$. In phase II-phase III, the transition appears at $T_{2}=347 / 343 \mathrm{~K}$ and its significant temperature hysteresis $(\Delta T=4 \mathrm{~K})$. Therefore, the transitions at $T_{1}$ and $T_{2}$ are typical for the first-order phase transition.

The entropy of the $\mathrm{I} \rightarrow \mathrm{II}$ and $\mathrm{II} \rightarrow \mathrm{III}$ phase transition at heating and cooling cycle is quite small $\left(\Delta S=0.07 \mathrm{~J} \mathrm{~g}^{-1} \mathrm{~K}^{-1}\right.$ at $T_{1}$ and $\Delta S=0.0146 \mathrm{~J} \mathrm{~g}^{-1} \mathrm{~K}^{-1}$ at $T_{2}$ ), and does not indicate the pure "order disorder" mechanism of this transition. This implies, from DSC results, that both order-disorder and displacive mechanism are expected for the phase transition. The mechanism experimentally observed in transition entropy can be interpreted in terms of Boltzmann's principle $\Delta S=R$ $\operatorname{Ln}(\Omega)$ [23], where $\Omega$ is the rapport number of distinguishable orientations allowed in the high- and the low-temperature phases. The observed values of $\Omega_{1}$ at $T_{1}$ and $\Omega_{2}$ at $T_{2} \sim 1$ $\left(\Omega_{1,2}<2\right)$ therefore do not indicate the pure "order disorder". As regards the DSC diagrams obtained from single crystals, they also show a weak peak (Fig. 4a) in the vicinity of $429 \mathrm{~K}$ $\left(T_{3}\right)$ prior to the melting temperature at $451 \mathrm{~K}$ ( $\left.T_{\text {melting }}\right)$. At this $T_{3}$ transition (from phase III to phase IV), the single crystals break and lose their transparency to become a white powder. This transition is not well shaped since it is too close to the melting point.

\section{Infrared and Raman spectra}

To gain more information on the crystal structure, we have undertaken a vibrational study using infrared spectroscopy and Raman scattering. The infrared and Raman spectra of the studied compound at room temperature are shown in Figs. 5 and 6. The assignments of the observed bands are realized by comparison with similar compounds [5, 13, 14, 24-27].

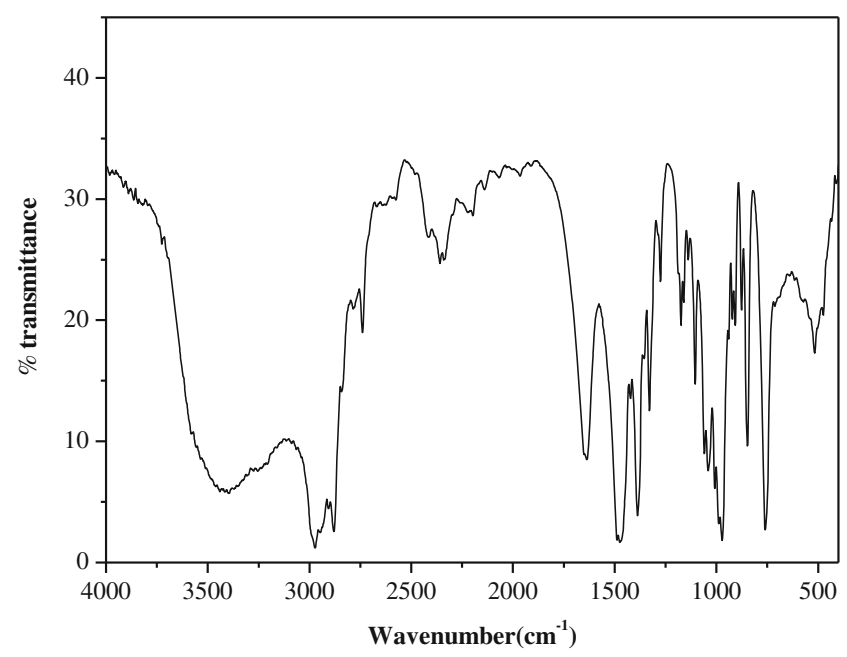

Fig. 5 Infrared spectrum of the $\left[\mathrm{N}_{(}\left(\mathrm{C}_{3} \mathrm{H}_{7}\right)_{4}\right]_{2} \mathrm{Zn}_{2} \mathrm{Cl}_{6}$ compound at room temperature in the $4,000-400 \mathrm{~cm}^{-1}$ range 


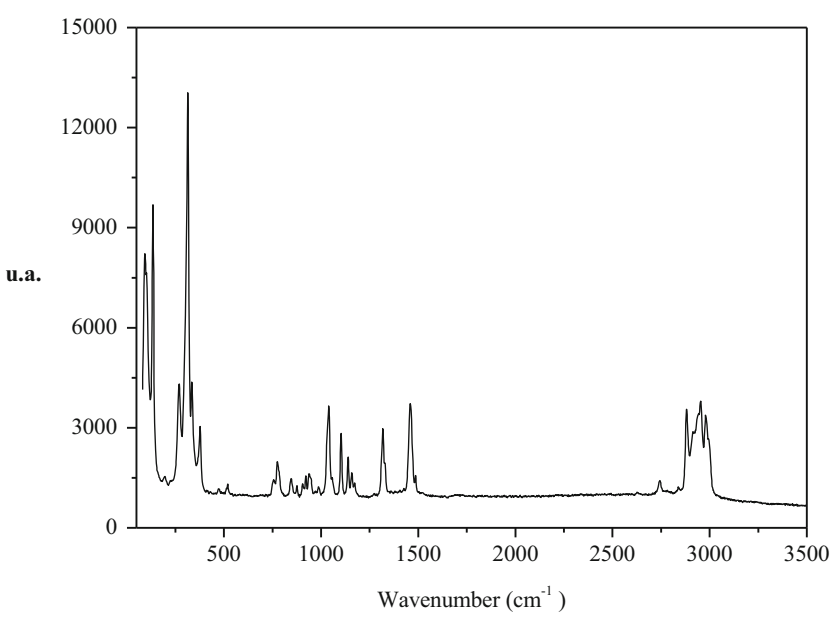

Fig. 6 Raman spectrum of $\left[\mathrm{N}\left(\mathrm{C}_{3} \mathrm{H}_{7}\right)_{4}\right]_{2} \mathrm{Zn}_{2} \mathrm{Cl}_{6}$ at room temperature in the $50-3,500 \mathrm{~cm}^{-1}$ spectral region

Besides, the wavenumbers of the observed peaks are quoted in Table 5.

While the principal bands are assigned to the internal modes of organic cation, the bands observed at 2,992, 2,973, and $2,986 \mathrm{~cm}^{-1}$ in IR and Raman, respectively, are accredited to the asymmetric $v_{\text {as }}\left(\mathrm{CH}_{3}\right), v_{\text {as }}\left(\mathrm{CH}_{2}\right)$ stretching mode. Concerning the $\mathrm{CH}$ stretching vibrations $v_{\mathrm{s}}\left(\mathrm{CH}_{2}\right)+v_{\mathrm{s}}\left(\mathrm{CH}_{3}\right)$, they are observed at 2,883 and $2,881 \mathrm{~cm}^{-1}$ in IR and Raman, respectively. The band which appears at 1,371 and $1,389 \mathrm{~cm}^{-1}$ in IR is related to the symmetric deformation $\delta_{\mathrm{s}}\left(\mathrm{CH}_{3}\right)$, whereas the bands observed at $1,470 \mathrm{~cm}^{-1}$ in IR and at $1,459 \mathrm{~cm}^{-1}$ in Raman can be assigned to the asymmetric deformation $\delta_{\text {as }}\left(\mathrm{CH}_{3}\right)$. Two sharp bands are observed at 1,310 and $1,330 \mathrm{~cm}^{-1}$ in IR, which are assigned to the $\omega\left(\mathrm{CH}_{2}\right)$ wagging modes. The frequencies observed at 1,174 and $1,318,1,139 \mathrm{~cm}^{-1}$ in infrared and Raman spectra, respectively, are related to the rocking $\rho_{\mathrm{r}}\left(\mathrm{CH}_{3}\right)$ vibration modes. Another band, assigned to the rocking $\rho_{\mathrm{r}}\left(\mathrm{CH}_{2}\right)$, is observed near 845 and $1,039 \mathrm{~cm}^{-1}$ in infrared and Raman, respectively. With respect to the bands observed at $943,973 \mathrm{~cm}^{-1}$ in IR and $937 \mathrm{~cm}^{-1}$ in Raman, they are assigned to $v_{1}\left(\mathrm{NC}_{4}\right)$ stretching modes. The deformation mode $v_{3}\left(\mathrm{NC}_{4}\right)$ appears at 757 and $776 \mathrm{~cm}^{-1}$ in IR and Raman spectra, respectively. The splitting bending mode $v_{\mathrm{s}}(\mathrm{CCCN})$ are observed at $1,103 \mathrm{~cm}^{-1}$ in infrared and Raman spectra. This mode may correspond to different conformers of the organic chains $\left[v_{\mathrm{s}}(\mathrm{NCC})+v_{\mathrm{s}}(\mathrm{CCC})\right]$. Moreover, the weak peak in infrared spectrum at $1,042 \mathrm{~cm}^{-1}$ is related to the bending mode $\left[v_{\mathrm{s}}(\mathrm{C}-\mathrm{C}-\mathrm{N})\right]$.

The Raman and IR active bands involving mainly the $\mathrm{Zn}_{2} \mathrm{Cl}_{6}$ vibration were proposed in comparison with $\mathrm{Ga}_{2} \mathrm{Cl}_{6}$ and $\mathrm{Cd}_{2} \mathrm{Cl}_{6}$. The isolated inorganic entities exhibit $\mathrm{D}_{2 \mathrm{~h}}$ symmetry with 18 normal modes. Among the $\mathrm{Zn}_{2} \mathrm{Cl}_{6}$ Raman active modes, the 474,333 , and $93 \mathrm{~cm}^{-1}$ lines can be assigned to the $3 \mathrm{Ag}\left(v_{1}, v_{2}\right.$, and $\left.v_{4}\right)$ and one band at $268 \mathrm{~cm}^{-1}$ attributed to the $\mathrm{B}_{1 \mathrm{~g}}\left(v_{6}\right)$ mode. Two modes $2 \mathrm{~B}_{2 \mathrm{~g}}\left(v_{11}, v_{12}\right)$ occur at 519 and $134 \mathrm{~cm}^{-1}$, respectively. The band observed at
Table 5 Assignments of observed in infrared and Raman spectra of $\left[\mathrm{N}\left(\mathrm{C}_{3} \mathrm{H}_{7}\right)_{4}\right]_{2} \mathrm{Zn}_{2} \mathrm{Cl}_{6}$

(1)

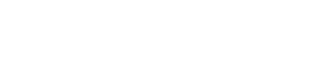

\begin{tabular}{llll} 
& 1,039 & $\rho_{\mathrm{r}}\left(\mathrm{CH}_{2}\right)$ \\
1,042 & & $\nu_{\mathrm{s}}(\mathrm{C}-\mathrm{C}-\mathrm{N})$ \\
1,103 & 1,103 & $\nu_{\mathrm{s}}(\mathrm{NCC})+v_{\mathrm{s}}(\mathrm{CCC})$ \\
1,174 & 1,139 & $\rho_{\mathrm{r}}\left(\mathrm{CH}_{3}\right)$ \\
1,275 & & $\tau\left(\mathrm{CH}_{2}\right)$ \\
1,310 & & $\omega\left(\mathrm{CH}_{2}\right)$ \\
& & 1,318 & $\rho_{\mathrm{r}}\left(\mathrm{CH}_{3}\right)$ \\
& 1,330 & & $\omega\left(\mathrm{CH}_{2}\right)$ \\
1,371 & & \}$\delta_{\mathrm{s}}\left(\mathrm{CH}_{3}\right)$ \\
1,389 & & \\
1,470 & 1,459 & $\delta_{\mathrm{as}}\left(\mathrm{CH}_{3}\right)$ \\
2,200 & & \\
2,337 & & \\
2,418 & & \\
2,575 & & \\
2,883 & 2,881 & $\nu_{\mathrm{s}}\left(\mathrm{CH}_{2}\right)+v_{\mathrm{s}}\left(\mathrm{CH}_{3}\right)$ \\
& & 2,954 & $v_{\mathrm{s}}\left(\mathrm{CH}_{3}\right)$ \\
& 2,973 & 2,986 & $v_{\mathrm{as}}\left(\mathrm{CH}_{3}\right)$ \\
& 2,992 & & $v_{\mathrm{as}}\left(\mathrm{CH}_{2}\right)$ \\
\hline stretching, $\rho$ rocking, $\delta$ \\
bending, $\omega$ wagging, $\tau$
\end{tabular}

$377 \mathrm{~cm}^{-1}$ should be attributed to $\mathrm{B}_{3 \mathrm{~g}}\left(v_{18}\right)$ mode at the Raman spectra. The $v_{1}$ and $v_{11}$ vibrations due to the $\mathrm{Zn}_{2} \mathrm{Cl}_{6}$ stretching motions and their frequencies are higher than those of $v_{2}, v_{6}$, and $v_{13}$, which are mainly due to the vibrations of the bridging $\mathrm{Zn}_{2} \mathrm{Cl}_{6}$ groups.

\section{Electrical conductivity}

The complex impedance spectra of the $\left[\mathrm{N}\left(\mathrm{C}_{3} \mathrm{H}_{7}\right)_{4}\right]_{2} \mathrm{Zn}_{2} \mathrm{Cl}_{6}$ compound recorded at different temperatures are shown in Fig. 7a and $b$. The well-defined semicircles either passing through or close to the origin were obtained at $303 \mathrm{~K} \leq T \leq 403 \mathrm{~K}$. As temperature increases, the radius of the arc corresponding to the bulk resistance of the sample decreases, indicating an activated thermal conduction mechanism. The depressed semicircles 


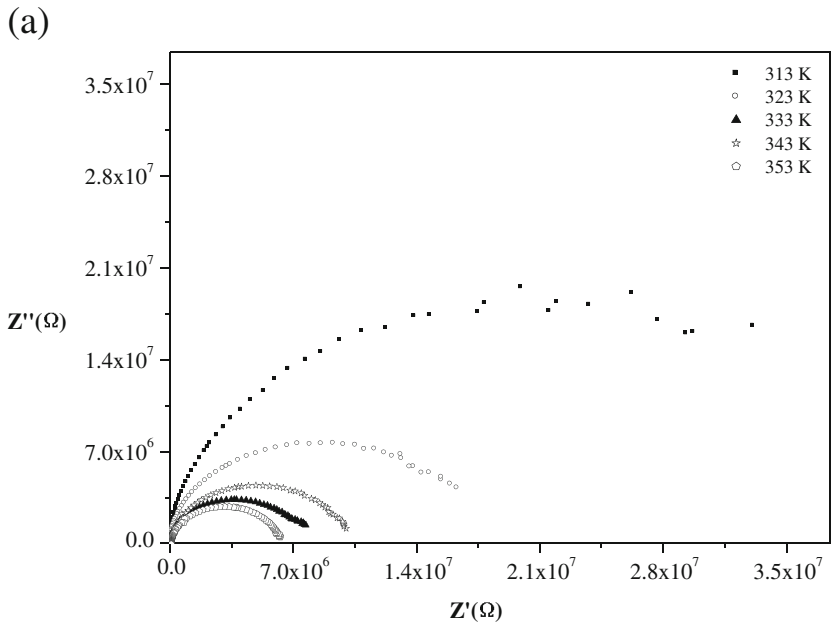

(b)

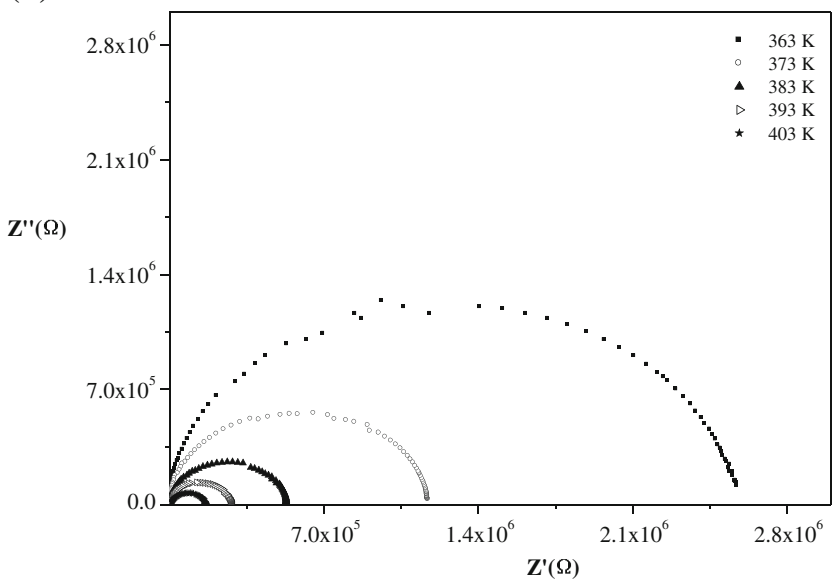

Fig. 7 The Cole-Cole plots at different temperature of the $\left[\mathrm{N}\left(\mathrm{C}_{3} \mathrm{H}_{7}\right)_{4}\right]_{2} \mathrm{Zn}_{2} \mathrm{Cl}_{6}$ compound

have their centers on a line below the real axis, which indicates the departure from the ideal Debye behavior [28].

The electrical conductivity $\sigma=e / R S$ ( $S$ is the electrolyteelectrode contact area and $e$ is the thickness of the sample) increases with the increase in temperature. In order to understand the conduction phenomena, we used the Arrhenius modeling equation [11]: $\sigma T=\mathrm{A} \exp \left(-E_{\mathrm{a}} / k T\right)$, where $E_{\mathrm{a}}$ is the activation energy, $A$ is the pre-exponential factor, $k$ is the Boltzmann constant, and $T$ is the temperature. The thermal evolution of the specific conductivity $[\operatorname{Ln}(\sigma T)$ vs. $1,000 / T]$ of bis tetrapropylammonium hexachloro-dizincate compound is shown in Fig. 8, indicating an Arrhenius-type behavior. In the 303-403 K temperature range, the conductivity plot exhibits one anomaly at $327 \pm(5) \mathrm{K}$. In comparison with the studied $\left[\mathrm{N}\left(\mathrm{C}_{3} \mathrm{H}_{7}\right)_{4}\right]_{2} \mathrm{Cd}_{2} \mathrm{Cl}_{6}$ compounds [13], this anomaly probably corresponds to the orientation and/or reorientation of molecular groups as $\left[\mathrm{N}\left(\mathrm{C}_{3} \mathrm{H}_{7}\right)_{4}\right]^{+}$. The obtained activation energy is $E_{\mathrm{a} 1}=0.69 \mathrm{eV}$ in phase I and $E_{\mathrm{a} 2}=0.96 \mathrm{eV}$ in phase II. The differences can be due to the high displacement of the ammonium proton caused by the cell deformation introduced with

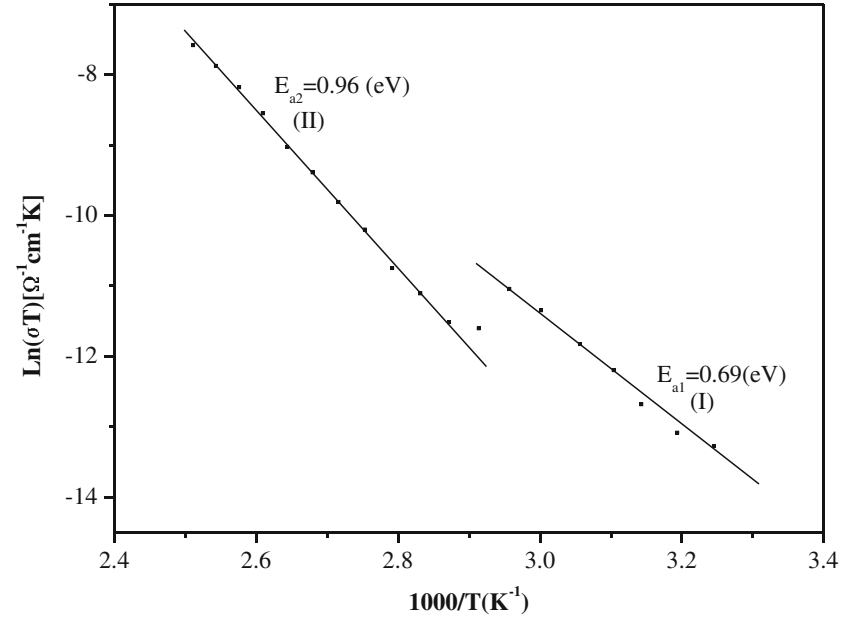

Fig. 8 Temperature dependence of $\operatorname{Ln}(\sigma T)$ versus reciprocal temperature for $\left[\mathrm{N}\left(\mathrm{C}_{3} \mathrm{H}_{7}\right)_{4}\right]_{2} \mathrm{Zn}_{2} \mathrm{Cl}_{6}$

the establishment of a non-polar phase, that is to say, the existence of a paraelectric phase at room temperature in the compound [29]. The anomaly is characterized by a sharp increase in the conductivity values, so the conductivity increases from $\sigma=2.2610^{-7}(\Omega \mathrm{cm})^{-1}$ at $303 \mathrm{~K}$ to $\sigma=1.6510^{-6}$ $(\Omega \mathrm{cm})^{-1}$ at $327 \mathrm{~K}$ for the first region, and from $\sigma=2.6010^{-6}$ $(\Omega \mathrm{cm})^{-1}$ at $333 \mathrm{~K}$ to $\sigma=1.3910^{-4}(\Omega \mathrm{cm})^{-1}$ at $403 \mathrm{~K}$ for the second one. The sudden conductivity variation at $327 \pm(5) \mathrm{K}$ marks the transitions, first to a more disordered state, which might be correlated with changes in the orientation of molecular groups as $\left[\mathrm{N}\left(\mathrm{C}_{3} \mathrm{H}_{7}\right)_{4}\right]^{+}$. The variation of conductivity at various temperatures confirms the occurrence of the phase transition at $327 \mathrm{~K}$ detected by the thermal analysis.

Figure $9 \mathrm{a}$ and $\mathrm{b}$ shows the variation of real part $\mathrm{Z}^{\prime}$ of the impedance at different temperatures. It is observed that all the curves merge in high-frequency region $\left(>10^{6} \mathrm{~Hz}\right)$, and then $Z^{\prime}$ becomes independent of frequency. Indeed, the magnitude of $Z^{\prime}$ decreases with the increase in both frequency and temperature indicating an increase in ac conductivity of the material. This result may be related to the release of space charge emanating from the reduction in the barrier properties of material with the rise in temperature [30].

The angular frequency dependence of the imaginary part $Z^{\prime \prime}$ of complex impedance of $\left[\mathrm{N}\left(\mathrm{C}_{3} \mathrm{H}_{7}\right)_{4}\right]_{2} \mathrm{Zn}_{2} \mathrm{Cl}_{6}$ at various temperatures is shown in Fig. 10a and b. The $Z^{\prime \prime}$ increases with the increase in frequency at all the temperatures, covered in the present study, and exhibits a maximum before it starts decreasing rapidly. The magnitude of $Z^{\prime \prime}$ maxima decreases gradually with the increase in both frequency and temperature, and it merges finally in the high-frequency region. This may possibly be an indication of the accumulation of space charge polarization effects in the material at lower frequency and at higher temperature [31]. 
(a)

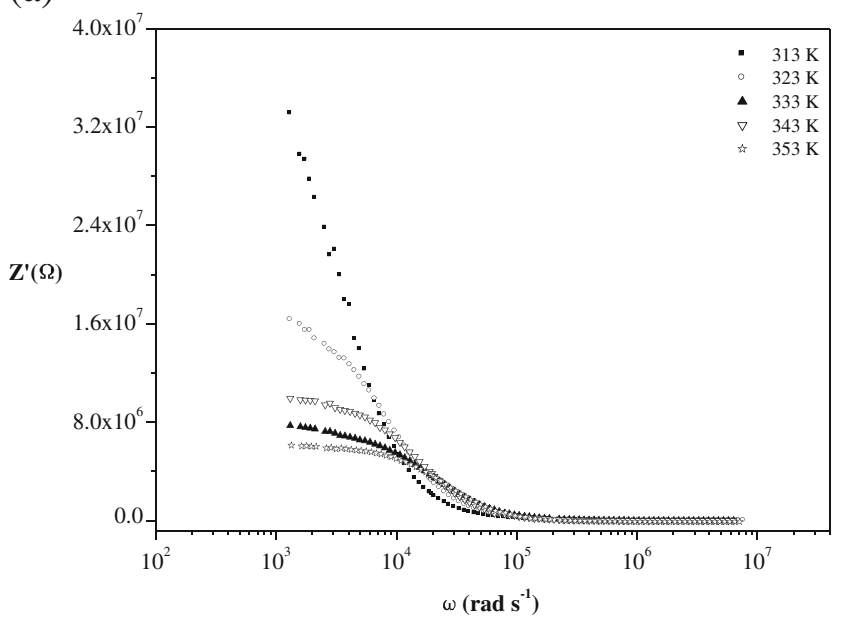

(b)

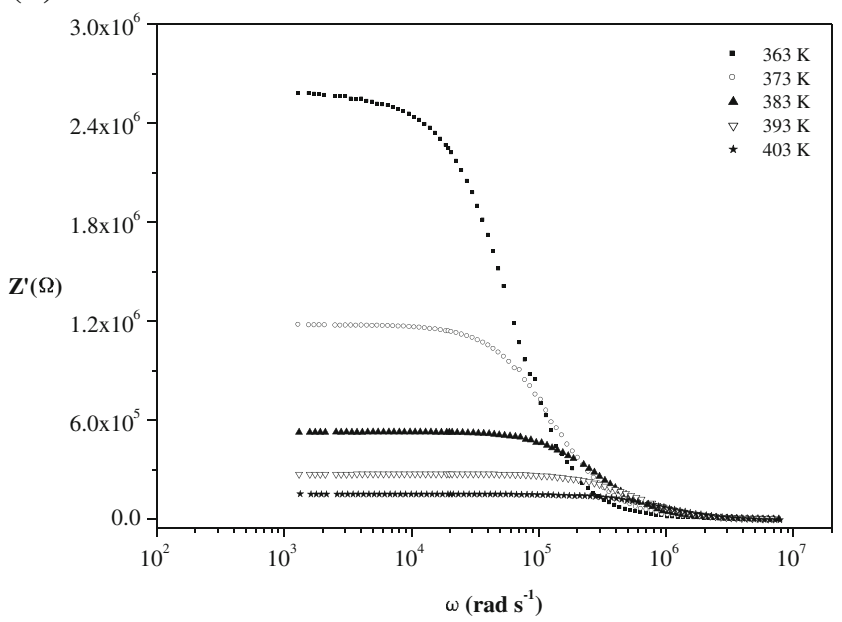

Fig. 9 Variation of $Z^{\prime}$ with angular frequency for $\left[\mathrm{N}\left(\mathrm{C}_{3} \mathrm{H}_{7}\right)_{4}\right]_{2} \mathrm{Zn}_{2} \mathrm{Cl}_{6}$ compound

\section{Ac conductivity}

The variation of alternating current (ac) conductivity as a function of frequency at different temperatures for the $\left[\mathrm{N}\left(\mathrm{C}_{3} \mathrm{H}_{7}\right)_{4}\right]_{2} \mathrm{Zn}_{2} \mathrm{Cl}_{6}$ is shown in Fig. 11. It is clear from the plot that the conductivity increases with the increase in frequency. From the previously mentioned figure, it is also evident that the dc contribution is important at low frequencies and high temperatures, yet in the low-frequency region, the conductivity depends on temperature. Such dependence may be described by the variable range hopping mechanism [32], which is frequency independent and only weakly dependent temperature compared with band theory. This model is important for the electrical conduction mechanism. The phenomenon of the conductivity dispersion is generally analyzed using Jonscher's law [33, 34]

$\sigma_{\mathrm{ac}}(\omega)=\sigma_{\mathrm{dc}}+A \omega^{n}$ (a)

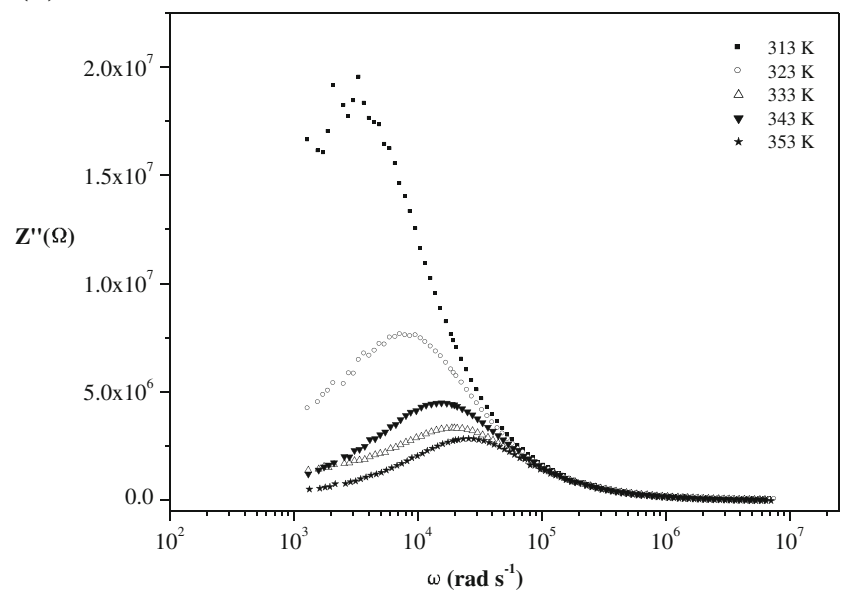

(b)

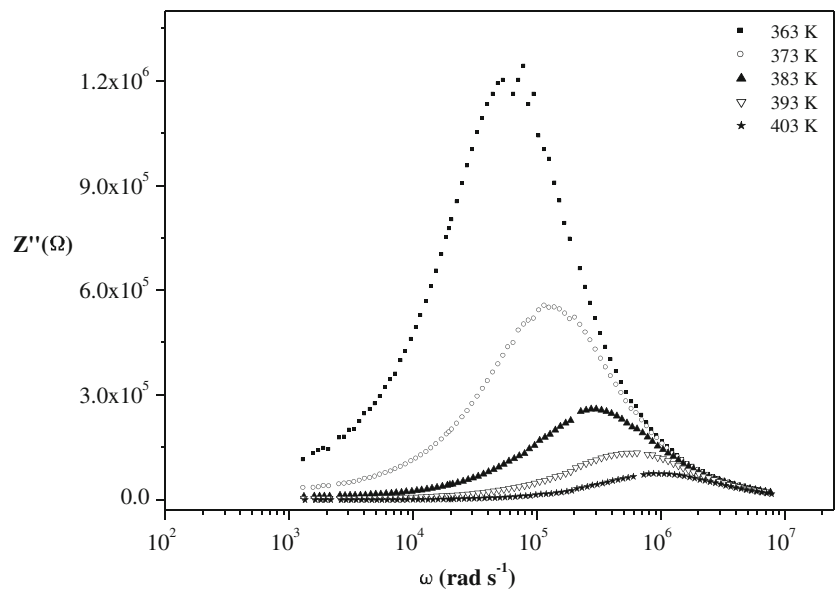

Fig. 10 Plots of the imaginary part of impedance at several temperatures

where $\sigma_{\mathrm{dc}}$ is the direct current conductivity of the sample, $n$ is the frequency exponent with $0<n<1$, and $A$ is the temperature dependent pre-exponential factor. This suggests that electrical

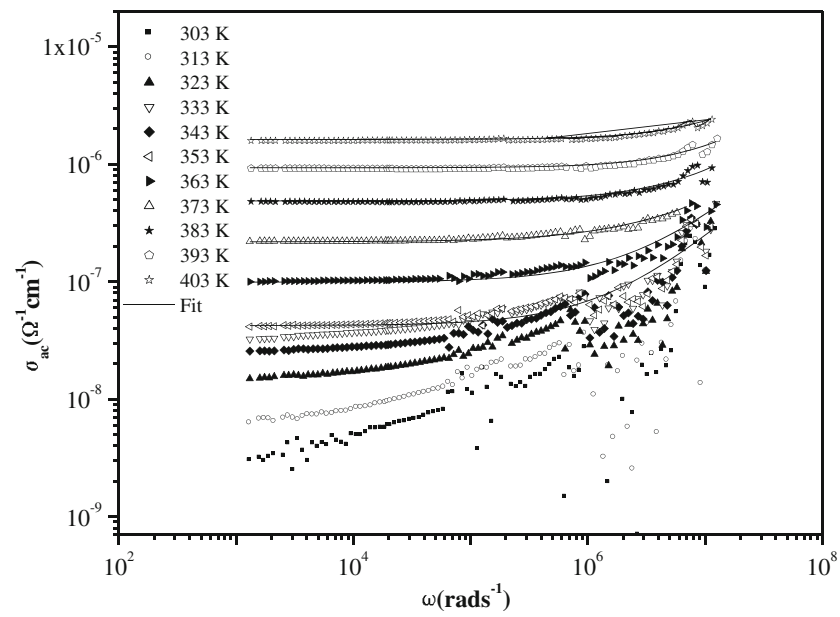

Fig. 11 Frequency dependence of the ac conductivity at various temperatures of the $\left[\mathrm{N}\left(\mathrm{C}_{3} \mathrm{H}_{7}\right)_{4}\right]_{2} \mathrm{Zn}_{2} \mathrm{Cl}_{6}$ compound 


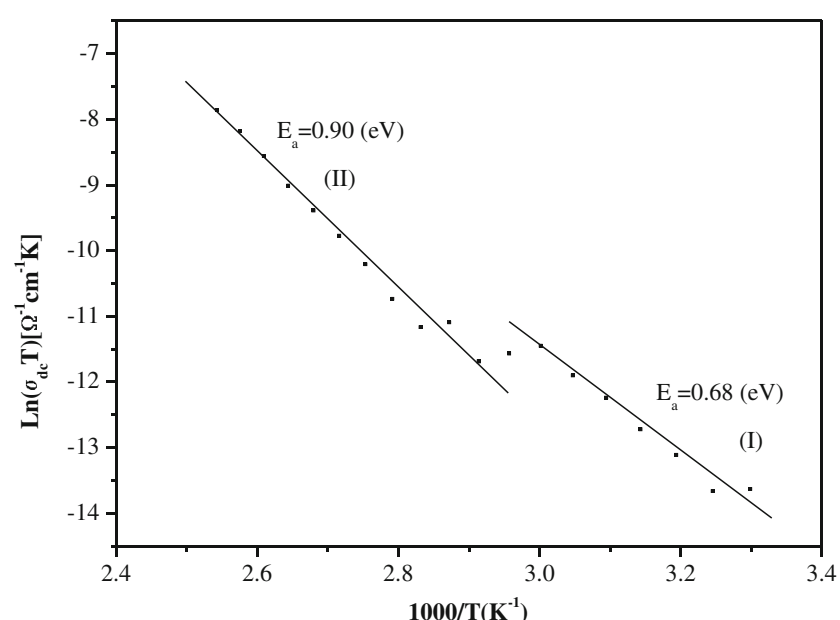

Fig. 12 Dependence of $\operatorname{Ln}\left(\sigma_{\mathrm{dc}} T\right)$ on temperature of $\left[\mathrm{N}\left(\mathrm{C}_{3} \mathrm{H}_{7}\right)_{4}\right]_{2} \mathrm{Zn}_{2} \mathrm{Cl}_{6}$ compound

conduction in $\left[\mathrm{N}\left(\mathrm{C}_{3} \mathrm{H}_{7}\right)_{4}\right]_{2} \mathrm{Zn}_{2} \mathrm{Cl}_{6}$ is a thermally activated process.

Dc conductivity data are plotted in Arrhenius format as $\operatorname{Ln}\left(\sigma_{\mathrm{dc}} T\right)$ versus $\left(10^{3} / T\right)$ (Fig. 12). Following the Arrhenius law, the obtained activation energy of the samples are $E_{\mathrm{a}}=0.68 \mathrm{eV}$ in region $\mathrm{I}(T<327 \mathrm{~K})$ and $0.90 \mathrm{eV}$ in region II $(T>333 \mathrm{~K})$. Those values are similar to the activation energy determined by impedance, suggesting that the near values of activation energies confirm that the transport is probably due to a hopping mechanism. The conduction is explained by the thermally activated mechanism. A change in the slope of the curve was observed at around $T=327 \pm(5) \mathrm{K}$ which is close to the temperature of the transition detected by DSC and electric measurement. The ionic conductivity here is considered to be induced by the reorientation of the tetra-ammonium alkyl chains [29]

\section{Conclusion}

The crystal structure of bis tetrapropylammonium hexachlorodizincate compound is built up of $\left[\mathrm{N}\left(\mathrm{C}_{3} \mathrm{H}_{7}\right)_{4}\right]^{+}$cation groups and bi-tetrahedral $\left[\mathrm{Zn}_{2} \mathrm{Cl}_{6}\right]^{-2}$ dimers connected to each other via electrostatic interaction. The compound is crystallized at room temperature in the triclinic system (space group $P \overline{1}$ ). In crystal structure, the inorganic layer, built up by $\mathrm{Zn}_{2} \mathrm{Cl}_{6}$ dimers, is connected to the organic ones through van der Waals interaction in order to build cation-anion-cation cohesion. The thermal investigation of the title crystal indicates the presence of four endothermic peaks at 327, 347, and 429. Two solid-solid reversible phase transitions of first order at $327 / 324$ and 347/343 K (heating/cooling) have been observed. The infrared and Raman studies confirm the presence of organic and inorganic groups.

The Cole-Cole plots of impedance complex measurements have been performed in the electric analysis. Besides, $Z^{\prime}$ and
$Z^{\prime \prime}$ curves which merge above $10^{6} \mathrm{~Hz}$ at different temperatures reveal the reduced space charge polarization and contribution from grain. The ac conductivity spectrum was found to obey Jonscher's universal power law, whereas dc conductivity shows a typical Arrhenius type of electrical conductivity. The near values of activation energies obtained from the impedance and dc conductivity spectra confirm that the transport is probably due to a hopping mechanism.

Open Access This article is distributed under the terms of the Creative Commons Attribution License which permits any use, distribution, and reproduction in any medium, provided the original author(s) and the source are credited.

\section{References}

1. Hrizi C, Chaari N, Abid Y, Boudjada NC, Chaabouni S (2012) Polyhedron 46:41

2. Mitzi DB, Brock P (2001) Inorg Chem 40:2096

3. Levola T, Laiho R (1988) Solid State Comm 66:557

4. Zamalloa GA, Rodriguez V, Couzi M, Sayetat F, Ferty P (1997) J Phys Condens Mater 9:937

5. Ben Rhaiem A, Hlel F, Guidara K, Gargouri M (2007) Spectrochimica Acta Part A 66:1107, 66

6. Kimizuka N, Kunitake T (1996) Adv Mater 8:89

7. Mitzi DB, Chondroudis K, Kagan CR (2001) IBM J Res Dev 45:1

8. Suzuki H, Notsu K, Takeda Y, Sugimoto W, Sugahara Y (2003) Chem Mater 15:636

9. Guloy AM, Tang Z, Miranda PB, Srdanov VI (2001) Adv Mater 13:833

10. Ben Rhaiem A, Hlel F, Guidara K, Gargouri M (2008) J Alloys Compd 463:440

11. Oueslati A, Hlel F, Guidara K, Gargouri M (2010) J Alloys Compd 492:508

12. Gesi K (1992) Ferroelectrics 137:209

13. Hannachi N, Guidara K, Bulou A, Hlel F (2010) Mater Res Bul 45:1754

14. Oueslati A, Chaabane I, Adil K, Hlel F (2012) J Chem 2013:1155

15. Oueslati A, Hlel F, Gargouri M (2011) Ionics 17:91

16. Sheldrick GM (2004) SADABS. University of Göttingen, Germany

17. SHELXS-97, Sheldrick GM (1986) Program for crystal structure solution. University of Göttingen, Germany

18. Betteridge PW, Carruthers JR, Cooper RI, Prout K, Watkin DJ (2003) J Appl Crystal 36:1487

19. Brandenburg K, Berndt M (1999) DIAMOND. Version 2. 1. b. Crystal Impact Gb R, Bonn

20. Hu G, Holt EM (1994) Acta Crystal C 50:1212

21. S. Moustarder, N. Mercier, P. Hudhomme, N. Gallego-Planas, A. Gorgues, A. Riou, Synth Met. (2002) 129

22. Baur WH (1974) Acta Crystal B 30:1195

23. Piecha A, Gagor A, Pietraszko A, Jakubas R (2010) J Solid State Chem 183:3058

24. Gosniowska M, Ciunik Z, Bator G, Jakubas R, Baran J (2000) J Mol Struct 555:243

25. Karbowiak M, Hanuza J, Janczak J, Drozdzynski J (1995) J Alloys Compd 225:338

26. Lin-Vien, Colthup NB, Fateley WG, Grasselli JG (1991) The handbook of infrared Raman characteristic frequencies of organic molecules. Academic, San Diego

27. Nakamoto K (1997) Infrared Raman spectra of inorganic and coordination compounds, 5th edn. Wiley, New York 
28. Ben Rhaiem A, Guidara K, Gargouri M, Daoud A (2005) J Alloys Compd 392:68

29. Khili H, Chaari N, Madani A, Ramond NR, Jaud J, Chaabouni S (2012) Polyhedron 48:146

30. Rao KS, Prasad DM, Krishna PM, Tilak B, Varadarajulu KC (2006) Mater Sci Eng B 133:141
31. Chandra KP, Prasad K, Gupta RN (2007) Physica B 388:118

32. Yakuphanoglu F, Aydogdu Y, Schatzschneider U, Rentschler E (2003) Solid State Comm 128:63

33. Khelifi M, Mkaouar I, Hlel F, Ben Salah A, Zouari R (2010) Ionics 16:709

34. Jonscher AK (1977) Nature 267:673 